\section{APPLIED BIOLOGY IN THE LEATHER INDUSTRY}

$\mathrm{T}$ HAT the leather industry forms an extensive field for research in applied chemistry has been well known for many years; that it forms a field, at least as extensive, for research in applied biology has been less well appreciated; and this notwithstanding the facts that the raw material of the industry is animal skin, that oils used by the industry and many tanning agents are plant products, that bacteria and moulds play havoc with certain of the processes of manufacture, and that insects cause damage to stored hides and finished leather. Clearly, in such an industry there must be opportunities for research in animal histology and physiology, as well as in microbiology, entomology and biochemistry; and some account of the problems presented in these various fields was given in a symposium held on March 21 at the Imperial College of Science and Technology by the Association of Applied Biologists in conjunction with the British Leather Manufacturers' Research Association.

The symposium was introduced by Sir Robert Pickard, who outlined the elaborate processes of leather manufacture, laying emphasis on the biological aspects and remarking that the problems of the industry call for co-operation between the statistician, the chemist, the physicist, the biologist and the psychologist, and directed attention to the fact that the tanner is handicapped by his raw material, the animal skin, over which he has very little control, as it is a by-product of other industries.

Discussing the factors that affect the animal skin, Mr. J. N. Turner stated that until comparatively recently the quality of skins received by the tanner did not vary greatly, and production of leather resolved itself into a relatively simple routine; but nowadays, with a wider market of supply and with advances in breeding and feeding techniques, many of which favour the milk- or meat-producing qualities of an animal at the expense of the leather-making properties of its skin, very wide variations are liable to occur that may necessitate certain changes in manufacture and in the resulting product. An acquaintance with recent trends in agricultural genetics and animal husbandry is therefore important to a modern leather manufacturer. It is only within the last decade that any attempt has been made to ascertain and measure the effects on the skin of crossbreeding and intensive feeding : for example, South African work has shown the effect of breed variations on the wearing quality of sole leather from cattle hides, and other work has indicated the effect of intensity of feed upon the fat content of hide and its bearing on grease stains in the finished leather. Differences in skin may also result from variations in climate and topography, and artificial changes may be induced by sex hormones, silicic acid or by compounds that stimulate mitosis.

Collagen, or white fibrous tissue, is the chief component of the animal skin from the leather industry's point of view. To the collagen fibres are due the properties of a leather, such as its tensile strength and resistance to abrasion; and much time has been devoted to the study of collagen by histologists and biochemists. In presenting some problems associated with reticulin, elastin and collagen in the skin, Miss M. Dempsey and Miss M. E. Garrod said that elastin and reticulin possess an importance out of all pro- portion to their amount. For reticulin fibrils that bind the collagen fibres together have a restrictive effect upon the swelling of collagen during the wide $p \mathrm{H}$ variations of the tannery processes ; and elastin, which occurs in the skin chiefly in both the papillary and the innermost layers, has a particular effect on that outer part of the skin that eventually becomes the 'grain' layer of the leather. One of the difficulties in their investigations was to isolate pure samples of the fibres from the animal skin; consequently work was done, for example, on reticulin from adipose tissue, elastin from ligamentum nuchæ, and on collagen from rat-tail tendon, the binding sheath of which consists of both elastin and reticulin. They are not certain, however, that findings on these easily accessible tissues are directly applicable to similar tissues in the skin.

That the study of the surface chemistry of the animal skin is of importance and interest to the industry was indicated by Dr. K. G. A. Pankhurst. The conversion of animal skin to leather involves the three main constituents of the skin : protein, lipoid and water. The globular proteins are largely removed, the fibrous proteins are chemically modified by tanning, the natural lipoids are usually removed at an early stage of the process and are replaced by others at the end, and the water content is considerably reduced. Dr. Pankhurst pointed out that the three phases allow of six possible interfaces: protein-lipoid, protein-water, protein-air, lipoidwater, lipoid-air, protein-air; and each presents peculiar problems to the tanner. Leather is composed of an interlacing network of fibres that creates a system of quasi capillaries; consequently, as it is always necessary to have a full control over the kind of liquid that flows through them, a knowledge of the chemistry and physics of the flow of liquids is important in many leather-making problems. The penetration of a liquid into a fibrous structure is dependent on $(a)$ the adhesion between fibre and liquid, $(b)$ the surface tension of the liquid, and (c) the size and spacing of the fibres in the surface. The effective angle of contact that the liquid makes with the skin is an index of the penetrability of the liquid into it : if the angle is $90^{\circ}$ or less the liquid will flow through; if it is greater than $90^{\circ}$ the liquid will not flow through unless a certain pressure is applied to it. Penetration problems arise in the soaking of dried skins, the removal of lipoids from wet skins, the re-introduction of lipoids after tanning, waterproofing, etc.

One of the more curious processes in leather manufacture is that of 'bating'. It is a pretanning process in which tryptic enzymes are allowed to act on the skin. When it is properly done a characteristic silky smoothness is produced in the finished leather. From the earliest days of the industry, bating has been done with the dung of certain animals; but in more recent times the use of these unpleasant materials has been largely replaced by the appropriate enzymes. In dealing with the use of enzymes in the industry, Dr. E. W. Merry confined his attention to the bating process. The enzymes are obtained chiefly from pig pancreas, but ox pancreas, fish viscera, bacteria and fungi are also used. It has been shown that a preparation of pure chymotrypsin from pancreas can produce a typical bated effect in a skin. However, the mixed proteolytic enzymes in a bate have various effects on the different skin proteins : it appears that they affect, to greater or lesser degrees, elastin, collagen, keratin and perhaps 
reticulin, and it has been suggested that they have an important effect on the erector pili muscles in the skin. It seems not unlikely that, in the future, bates may be made up with specified enzymes, so that the different proteins of the skin may be preferentially attacked according to the class of leather desired.

Bacteria are notorious in the industry as the cause of putrefaction and, in the form of anthrax, as a danger to operatives. In their paper on this aspect, Dr. M. E. Robertson and Miss B. M. Haines said that putrefaction is usually prevented either by drying the hides after flaying or by treating them with sodium chloride as a preservative. The treatment of hides with a salt of marine origin, however, is likely to encourage a growth of red halophilic bacteria, known to tanners as 'red heat'; but this can be prevented by the addition of sodium fluoride to the salt. The use of disinfectants is also recommended in the process known as soaking, during which bacterial damage is especially common. The important process of liming kills all active stages of bacteria, but some spores (including those of anthrax) can survive; these can be killed by 'drumming' in lime and sodium sulphide at a raised temperature. Bacteria can, however, sometimes be of use to the industry : in America, bacteria producing lactic acid are used to promote the necessary acidity in the tan liquors, but in Great Britain the method is regarded as too difficult to control.

During many of the stages from skin to finished leather, mould fungi occur : except as a source of bating enzymes, they are a nuisance. The industry has also its insect pests, the chief being, perhaps, the beetles of the genus Dermestes. Mr. A. J. Musgrave, dealing with mycological and entomological problems, outlined the damage caused by fungi in the various processes. It is well known that vegetable-tanned leather is a better substrate for fungal growth than that which has been chrome-tanned; but the kind of processing a leather has received affects its liability to mould growth ; moreover, there is need for a fuller acquaintance with the species of fungi that occur in the industry, and of the damage that they cause. A number of fungicides are available to the industry, which has wisely made use of available knowledge; and there are various ways in which fungicides can be incorporated in leather, though its multifarious uses make every proofing problem worthy of individual attention.

A considerable number of insects associated with the industry has been recorded. The chief pests seem to be warble flies, attacking the living skin, Dermestes beetles on dried hides, clothes-moths and carpet beetles on furs, and various insects attacking leather in the tropics. In addition, the fly Piophila casei is a considerable nuisance. It appears that the most systematic efforts at control have been those directed against Dermestes beetles : for many years arsenication of dried hides has been practised. The difficulties encountered in carrying out laboratory tests on insecticides and fungicides for the industry were discussed : some simple preliminary experiments have indicated that 'Gammexane' may be more toxic than D.D.T. to Dermestes maculatus.

Finally, when the leather has been manufactured, it may be found to be faulty in some way, or a tanner may realize during manufacture that there is some irregularity. A method in leather biology that is indispensable in investigating these faults and in controlling the various processes is a specialized branch of animal histology : the study of the fibre structure of skins and leather. In dealing with this subject, Miss M. Dempsey stipulated that it is the task of the student of fibre structure to attempt to correlate what he sees with the physical properties of the leather and with the kind of processing it has undergone. The condition of the collagen fibre bundles and their manner of interweaving constitutes, sensu strictu, the fibre structure of the leather : the history of a leather is written in the appearance of its fibre bundles. The properties of a leather, she said, are dependent on its fibre structure, the appearance of which not only gives information about the suitability of a process, but also indicates the quality of the leather, and, more important still, may reveal the cause of a flaw, such, for example, as skin disease or putrefaction, chemical breakdown during manufacture or maltreatment in use. The various features of fibre structure were described and their practical importance indicated.

A fuller account of this meeting is to be published in the Annals of Applied Biology.

\section{RESEARCH AND INDUSTRY IN SCOTLAND}

$\mathrm{T}$ HE Scottish Regional Conference on "Research and the Progress of Industry in Scotland" arranged by the Federation of British Industries and held at the Merchants' Hall, Glasgow, on April 25, was on similar lines to that of the Midlands Regional Conference of the Federation at Birmingham in March. A message from Sir Edward Appleton wishing the Conference success contained, however, perhaps the most important statement made there. After indicating that the Department of Scientific and Industrial Research had been giving a good deal of attention to the question of the diffusion of scientific knowledge, and was looking to these conferences for guidance as to how best to deploy the limited scientific effort of Great Britain, Sir Edward said that to improve the Department's contacts with Scottish industry it is arranging to open a Scottish branch of the recently created Intelligence Division; and he cordially invited firms to discuss their special problems with the Department when that branch had been opened.

The morning session of the Conference considered the established industries of the region, Mr. W. Barr dealing with research in the steel industry, followed by Sir Wilfred Ayre on research in the shipbuilding industry and Mr. W. G. Marshall on research in the heavy engineering industries. Mr. Barr referred particularly to the recruitment of workers with technical knowledge in order that the results of research may be utilized. Steelmaking, so long practised as an art, is slowly becoming a science founded on the laws of physical chemistry, but much remains to be done before the desirable degree of control throughout the process is attained. Sir Wilfred Ayre, pointing out that the Scottish industry should not be differentiated from the larger British shipbuilding industry of which it is a part, suggested that the application of science in the industry would be facilitated if firms were readier to present the results of their research either in papers before technical institutions or to the industry's research association. He referred particularly to the valuable contribution of the various technical institutions, as well as to the work of the classification societies, and to the important 